[Regular Paper]

\title{
Partial Oxidation of Methane to Synthesis Gas over Oxidized Diamond Supported Catalysts-Catalytic Behavior of Nickel and Cobalt Species-
}

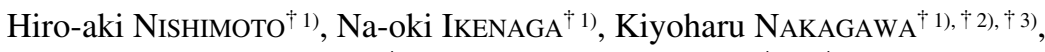 \\ Toru KoNISHI ${ }^{\dagger 1)}$, and Toshimitsu SUZUKI ${ }^{\dagger 1) *, \dagger 2)}$ \\ †1) Dept. of Chemical Engineering, Kansai University, Suita, Osaka 564-8680, JAPAN \\ †2) High Technology Research Center, Kansai University, Suita, Osaka 564-8680, JAPAN \\ †3) Japan Science Technology Corp. (JST) and National Institute for Materials Science (NIMS), \\ 1-1 Namiki, Tsukuba, Ibaraki 305-0044, JAPAN
}

(Received December 7, 2004)

\begin{abstract}
Characterization of nickel and cobalt catalysts supported on oxidized diamond (O-dia) in the partial oxidation of methane to synthesis gas was carried out by X-ray photoelectron spectroscopy (XPS) and the transient response pulse technique. Carbon deposition occurred on nickel/O-dia, but not on cobalt/O-dia catalyst at $873 \mathrm{~K}$ throughout prolonged reaction. XPS analyses observed partially reduced nickel oxides on nickel/O-dia catalyst after reaction with methane/oxygen $(5 / 1)$ at $873 \mathrm{~K} . \mathrm{Co}(0)$, partially reduced cobalt oxide, and $\mathrm{Co}(\mathrm{III})$ oxide phases were found on cobalt/O-dia catalyst after reaction at $873 \mathrm{~K}$. Transient response methane/oxygen (2/1) pulse studies found a large amount of hydrogen production occurred immediately at $873 \mathrm{~K}$ over the nickel/O-dia catalyst. However, a very small amount of hydrogen production was seen over the cobalt/O-dia catalyst, indicating that nickel and cobalt species supported on O-dia exhibited different behavior. Transient response of the catalyst bed temperature found that endothermic reaction occurred on the nickel/O-dia catalyst at $873 \mathrm{~K}$, but exothermic reaction proceeded on the cobalt/O-dia catalyst. These results suggest that methane decomposition to hydrogen is the primary reaction path over nickel/O-dia catalyst, whereas complete oxidation is the primary reaction followed by steam and carbon dioxide reforming to produce synthesis gas over the cobalt/O-dia catalyst.
\end{abstract}

\section{Keywords}

Partial oxidation, Diamond, Methane, Synthesis gas, Pulse method

\section{Introduction}

Partial oxidation of methane to synthesis gas is an energy saving exothermic process that is currently attracting much attention, after the re-evaluation by Aschcroft $e$ t al. ${ }^{1)}$, and several review articles have summarized the research in this field ${ }^{2,3)}$. Two reaction courses have been proposed: direct conversion of methane to hydrogen and carbon monoxide on the catalyst surface (reaction 1), and sequential reaction paths involving complete oxidation (reaction 4) followed by steam and carbon dioxide reforming (reactions 5 and 6) with unreacted methane ${ }^{4}$. Most investigations have dealt with sequential reaction paths ${ }^{4}$. Direct paths to give hydrogen and carbon monoxide, more accurately reactions (2) and (3), were proposed for Pt-loaded monolith catalyst under very high space velocity ${ }^{5}$. We have summarized our research on nickel or cobalt loaded catalyst for the partial oxidation of methane ${ }^{6}$.

\footnotetext{
* To whom correspondence should be addressed.

* E-mail: tsuzuki@ipcku.kansai-u.ac.jp
}

$$
\begin{aligned}
& \mathrm{CH}_{4}+1 / 2 \mathrm{O}_{2} \longrightarrow 2 \mathrm{H}_{2}+\mathrm{CO} \\
& \mathrm{CH}_{4} \rightleftarrows \mathrm{C} \text { (Catalyst) }+2 \mathrm{H}_{2} \\
& \mathrm{C}(\text { Catalyst })+1 / 2 \mathrm{O}_{2} \longrightarrow \mathrm{CO}=74.8 \mathrm{~kJ} / \mathrm{mol} \\
& \mathrm{CH}_{4}+2 \mathrm{O}_{2} \longrightarrow \mathrm{CO}_{2}+2 \mathrm{H}_{2} \mathrm{O} \\
& \Delta \mathrm{H}=-110.5 \mathrm{~kJ} / \mathrm{mol}(3) \\
& \mathrm{CH}_{4}+\mathrm{H}_{2} \mathrm{O} \rightleftarrows 390 \mathrm{~kJ} / \mathrm{mol} \\
& \mathrm{CH}_{2}+\mathrm{CO}+\mathrm{CO}_{2} \rightleftarrows 2 \mathrm{H}_{2}+2 \mathrm{CO} \\
& \Delta \mathrm{H}=206 \mathrm{~kJ} / \mathrm{mol}
\end{aligned}
$$

We are interested in the unique properties of the diamond surface, and have developed various reactions using catalysts supported on oxidized diamond (Odia $)^{7) \sim 11)}$. Diamond surface is easily oxidized by oxidative acids such as $\mathrm{HNO}_{3}, \mathrm{HClO}, \mathrm{H}_{2} \mathrm{O}_{2}$, etc., and is also oxidized by $\mathrm{O}_{2}$ at high temperatures to form $\mathrm{C}-\mathrm{O}-\mathrm{C}$ ether type structures and $\mathrm{C}=\mathrm{O}$ carbonyl type structure $^{12)}$. Transition metals loaded on various metal oxide supports exhibit metal support interactions and sometimes form binary oxides ${ }^{13) \sim 16)}$. In contrast, O- 
dia cannot form complex oxides with the loaded metal or metal oxide, or may not have strong interactions with loaded species. Therefore, the characteristic features of the loaded species will be preserved.

Previously, we reported that nickel and cobalt catalyst supported on O-dia exhibited high catalytic activity for the partial oxidation of methane ${ }^{6)}$ and carbon dioxide reforming of methane ${ }^{11)}$ at the low temperature of 873 K. Nickel O-dia catalyst developed considerable carbon deposition during the partial oxidation reaction at $873 \mathrm{~K}$. However, no carbon deposition was seen at 973 K. Cobalt O-dia catalyst showed slightly lower activity compared to nickel catalyst, but no carbon deposition was observed in the temperature range investigated. Product distributions were different for the nickel and cobalt O-dia catalysts, indicating that different reaction mechanisms occurred.

We proposed the transient response of temperature jump technique to evaluate exothermic $(1,4)$ and endothermic $(2,5,6)$ reactions by measuring the catalyst bed temperature response to methane/oxygen pulse injection ${ }^{17), 18)}$. Iridium titania catalyst exhibited a very large temperature increase at the front edge of the catalyst bed with the introduction of the methane/oxygen $(2 / 1)$ pulse, suggesting that highly exothermic complete oxidation proceeded as the first step, followed by endothermic reactions (5) and (6). In contrast, rhodium titania catalyst exhibited a temperature decrease at the front edge of the catalyst bed with the introduction of the methane/oxygen (2/1) pulse, suggesting a direct pathway to synthesis gas through reactions (2) and $(3)^{17), 18)}$.

In this paper, we will deal with X-ray photoelectron spectroscopy and the temperature jump technique, to investigate the reaction pathways of nickel and cobaltloaded O-dia catalysts.

\section{Experimental}

\section{1. Catalyst Preparation and Partial Oxidation Reaction}

Commercial fine powdered diamond (General Electric Co., particle diameter less than $0.5 \mathrm{~mm}$ ) was first hydrogenated at $1173 \mathrm{~K}$ for $1 \mathrm{~h}$ under a pure hydrogen stream to prepare homogeneous surface conditions. The hydrogenated diamond powder was then oxidized at $723 \mathrm{~K}$ for $1 \mathrm{~h}$ under an oxygen stream (oxygen/argon = $1 / 4$ ) to prepare the O-dia. The supported metal catalysts were prepared by impregnating an aqueous solution of $\mathrm{Co}\left(\mathrm{NO}_{3}\right)_{2} \cdot 6 \mathrm{H}_{2} \mathrm{O}, \mathrm{RuCl} \cdot n \mathrm{H}_{2} \mathrm{O}, \mathrm{Pd}\left(\mathrm{CH}_{3} \mathrm{COO}\right)_{2}$, $\mathrm{IrCl}_{4} \cdot \mathrm{H}_{2} \mathrm{O},\left(\mathrm{NH}_{3}\right)_{2} \mathrm{Pt}\left(\mathrm{NO}_{2}\right)_{2}$, and $\mathrm{RhCl}_{3} \cdot \mathrm{H}_{2} \mathrm{O}$ (Mitsuwa Pure Chemicals Co. $), \mathrm{Fe}\left(\mathrm{CO}_{3}\right)_{3} \cdot 9 \mathrm{H}_{2} \mathrm{O}$, and $\mathrm{Ni}\left(\mathrm{NO}_{3}\right)_{2}$. $6 \mathrm{H}_{2} \mathrm{O}$ (Wako Pure Chemical Industries, Ltd.). After evaporating excess water, the catalyst was calcined in air at $723 \mathrm{~K}$ for $1 \mathrm{~h}$.

\section{2. Partial Oxidation Reaction}

Partial oxidation of methane was carried out with a micro fixed bed flow reactor made of quartz (i.d. $8 \mathrm{~mm} \times$ $350 \mathrm{~mm}$ ) operated at atmospheric pressure. The catalyst $(60 \mathrm{mg})$ was maintained at temperatures of 673 $973 \mathrm{~K}$ and a flow of $25 \mathrm{ml} / \mathrm{min}$ of methane and 5 $\mathrm{m} l / \mathrm{min}$ of oxygen was passed. Products were analyzed with an online high speed gas chromatograph equipped with CP-Sil 5 and Mol-plot columns (PCChrom, M200 Chromato Analyzer).

\section{3. Transient Response Measurement}

Transient response measurement of the catalyst bed temperature to pulsed reactions was carried out using a fixed bed quartz reactor $(4 \mathrm{~mm}$ i.d. $\times 200 \mathrm{~mm}$ ). Thin wall sheathed thermocouples were positioned in the front edge of the catalyst bed, and the catalyst $(100 \mathrm{mg})$ was charged. A pulse of methane/oxygen (2/1) was introduced with a 6-port gas sampling valve equipped with measuring tubes $(1.0$ and $3.0 \mathrm{ml})$ in a stream of argon carrier gas $(50 \mathrm{ml} / \mathrm{min})$. Before the reaction, the catalyst was reduced under a hydrogen flow for $1 \mathrm{~h}$ at $873 \mathrm{~K}$. The reaction temperature was controlled with a programmable controller by monitoring the outside temperature of the reactor wall. Analyses of the effluent gases during the pulsed reaction of methane and oxygen were made using an on-line quadrupole mass spectrometer (HAL201, Hiden Analytical Ltd.). The mass spectrometer scanned the parent peaks of the 5 compounds (hydrogen, carbon monoxide, carbon dioxide, oxygen, and methane) within $1 \mathrm{~s}$, and repeated scans were collected in a personal computer.

Methane decomposition was carried out under the same conditions as the pulsed temperature jump measurement, by changing the steady flow of argon (10 $\mathrm{m} l / \mathrm{min}$ ) to a constant flow of pure methane (10 $\mathrm{m} / / \mathrm{min}$ ).

\section{4. Characterization}

X-Ray photoelectron spectroscopy (XPS) of the catalyst used a JEOL model JPS-9000MX with Mg K $\alpha$ radiation as the energy source. The spectrum was calibrated with $\mathrm{Pt}_{4} \mathrm{f}_{1 / 2}$ at $70.9 \mathrm{eV}$. Reduced or used catalyst samples were placed in a platinum boat under an inert atmosphere and transferred into the XPS instrument using a transfer vessel.

\section{Results and Discussion}

\section{1. Activity of Nickel and Cobalt-loaded O-dia Catalysts}

Partial oxidation of methane was carried out using various group VIII metal O-dia catalysts as shown in Table 1. Nickel and cobalt catalysts showed high activity for synthesis gas formation. Second row group 15-17 transition metals are highly active for this reaction $^{2)}$, but exhibited only moderate to low activity when supported on O-dia. Carbon deposition was 
Table 1 Activity of Various O-dia Supported Transition Metal Catalysts for the Partial Oxidation of Methane

\begin{tabular}{|c|c|c|c|c|c|c|c|}
\hline \multirow{2}{*}{ Entry } & \multirow{2}{*}{ Catalyst } & \multirow{2}{*}{$\begin{array}{c}\text { Conversion [\%] } \\
\mathrm{CH}_{4}\end{array}$} & \multicolumn{3}{|c|}{ Selectivity [\%] } & \multirow{2}{*}{$\begin{array}{l}\mathrm{H}_{2} / \mathrm{CO} \\
\text { (ratio) }\end{array}$} & \multirow{2}{*}{$\begin{array}{c}\text { Carbon } \\
\text { deposition }\end{array}$} \\
\hline & & & $\mathrm{CO}$ & $\mathrm{CO}_{2}$ & $\mathrm{H}_{2}$ & & \\
\hline 1 & Nickel/O-dia & 26.2 & 72.5 & 27.5 & 87.3 & 2.4 & $\bigcirc$ \\
\hline 2 & Nickel/O-dia ${ }^{\text {b) }}$ & 30.3 & 86.2 & 13.7 & 72.6 & 1.7 & - \\
\hline 3 & Cobalt/O-dia & 22.9 & 68.0 & 32.1 & 77.6 & 2.3 & - \\
\hline 4 & Cobalt/O-dia ${ }^{\text {b) }}$ & 29.3 & 79.8 & 20.5 & 79.8 & 1.8 & - \\
\hline 5 & Ruthenium/O-dia & 19.3 & 62.5 & 37.5 & 76.6 & 2.4 & - \\
\hline 6 & Rhodium/O-dia & 14.2 & 52.9 & 47.1 & 78.7 & 2.5 & - \\
\hline 7 & Palladium/O-dia & 13.8 & 50.9 & 49.1 & 77.6 & 3.1 & $\bigcirc$ \\
\hline 8 & Iridium/O-dia & 9.4 & 30.1 & 69.9 & 57.1 & 4.6 & - \\
\hline 9 & Iron/O-dia & 8.7 & 4.7 & 95.4 & - & - & - \\
\hline 10 & Platinum/O-dia & 7.9 & - & 100 & - & - & - \\
\hline 11 & O-dia & 6.1 & - & 100 & - & - & - \\
\hline
\end{tabular}

a) $873 \mathrm{~K}$, Flow rate: $30 \mathrm{ml} / \mathrm{min}\left(\mathrm{CH}_{4} / \mathrm{O}_{2}=5\right)$, Space velocity: $30,000 \mathrm{~h}^{-1} \cdot \mathrm{ml} / \mathrm{g}$-catalyst, Catalyst: $60 \mathrm{mg}$ (as prepared catalyst), Metal loading level: $3 \mathrm{wt} \%$.

b) at $973 \mathrm{~K}$.

Table 2 Activity of Reduced and as Prepared Cobalt Catalysts for the Partial Oxidation of Methane ${ }^{\text {a) }}$

\begin{tabular}{|c|c|c|c|c|c|c|}
\hline \multirow{2}{*}{ Entry } & \multirow{2}{*}{ Support } & \multirow{2}{*}{$\begin{array}{l}\text { Conversion [\%] } \\
\qquad \mathrm{CH}_{4}\end{array}$} & \multicolumn{3}{|c|}{ Selectivity [\%] } & \multirow{2}{*}{$\begin{array}{l}\mathrm{H}_{2} / \mathrm{CO} \\
\text { (ratio) }\end{array}$} \\
\hline & & & $\mathrm{CO}$ & $\mathrm{CO}_{2}$ & $\mathrm{H}_{2}$ & \\
\hline 12 & $\mathrm{Al}_{2} \mathrm{O}_{3}\left(\mathrm{H}_{2}\right.$ reduced $)$ & 24.6 & 74.1 & 25.9 & 79.6 & 2.2 \\
\hline 13 & $\mathrm{Al}_{2} \mathrm{O}_{3}$ (no reduction) & 3.1 & - & 100.0 & - & - \\
\hline 14 & O-dia (no reduction) & 22.1 & 64.1 & 35.9 & 75.6 & 2.4 \\
\hline 15 & $\mathrm{La}_{2} \mathrm{O}_{3}$ (no reduction) & 9.4 & - & 100 & 1.5 & - \\
\hline 16 & $\mathrm{MgO}$ (no reduction) & 8.2 & - & 100 & 8.4 & - \\
\hline 17 & $\mathrm{TiO}_{2}$ (no reduction) & 7.6 & 13.4 & 86.6 & 4.4 & 0.7 \\
\hline 18 & Graphite (no reduction) & 7.2 & - & 100 & - & - \\
\hline 19 & $\mathrm{SiO}_{2}$ (no reduction) & 0.4 & - & 100 & - & - \\
\hline 20 & $\mathrm{SiO}_{2}\left(\mathrm{H}_{2}\right.$ reduced $)$ & 1.0 & 0.0 & 100 & - & - \\
\hline 21 & Active carbon (no reduction) & - & - & - & - & - \\
\hline 22 & $\mathrm{Ni} / \mathrm{SiO}_{2}{ }^{\text {b) }}$ (no reduction) & 0.0 & - & - & - & - \\
\hline 23 & $\mathrm{Ni} / \mathrm{SiO}_{2}{ }^{\mathrm{b})}\left(\mathrm{H}_{2}\right.$ reduced $)$ & 27.2 & 74.6 & 26.3 & 76.5 & 2.6 \\
\hline
\end{tabular}

a) $873 \mathrm{~K}$, Flow rate: $30 \mathrm{ml} / \mathrm{min}\left(\mathrm{CH}_{4} / \mathrm{O}_{2}=5\right)$, Catalyst: $60 \mathrm{mg}$, Cobalt loading level: $3 \mathrm{wt} \%, \mathrm{H}_{2}$ reduction: $\mathrm{H}_{2}=10$ $\mathrm{ml} / \mathrm{min}(873 \mathrm{~K}, 1 \mathrm{~h})$.

b) $\mathrm{Ni} / \mathrm{SiO}_{2}$ catalyst.

observed on nickel or palladium catalyst under methane/oxygen (5/1) flow at $873 \mathrm{~K}$ after $2 \mathrm{~h}$. Carbon deposition on O-dia catalysts was measured during isothermal reaction at $873 \mathrm{~K}$ with hydrogen/argon mixed gas after hydrogen pre-treatment at the same temperature using thermogravimetry (TG). However, no carbon deposition was observed at 923 and $973 \mathrm{~K}$. Cobalt catalyst showed no carbon deposition irrespective of the reaction temperature. The activity of nickel and cobalt O-dia catalysts for the partial oxidation of methane was described previously). Ni/Odia catalyst provided high methane conversion of $30 \%$ into carbon monoxide and hydrogen with selectivity of over $72 \%$ at $973 \mathrm{~K}$. No deactivation of the nickel/Odia catalyst was observed by carbon deposition during the reaction at $973 \mathrm{~K}$ for $10 \mathrm{~h}$. Cobalt/O-dia catalyst showed similar but slightly lower activity for the partial oxidation of methane.

Freshly prepared (without hydrogen reduction) nickel and cobalt silica catalysts achieved very low methane conversion at $873 \mathrm{~K}$ (Table 2). Silicone is located below carbon in group 14 of the Periodic Table, and is frequently used as a support material for catalysts. Odia was employed as pseudo solid carbon oxide phase $^{6) \sim 11)}$. Such large differences in the effect of silica and O-dia surfaces on partial oxidation is difficult to explain at present. The interaction between metal oxide and the O-dia surface seems to be weak, and consequently the oxide could be easily reduced to lower valence species. Therefore, XPS was performed to obtain information about the nickel and cobalt valence states.

\section{2. Active Form of Nickel on the Nickel/O-dia Catalyst}

Nickel/O-dia catalyst exhibited high activity for the partial oxidation of methane at $873 \mathrm{~K}$, whereas nickel/silica catalyst had no activity (Table 2 ). The XPS differences in nickel/O-dia and nickel/silica cata- 


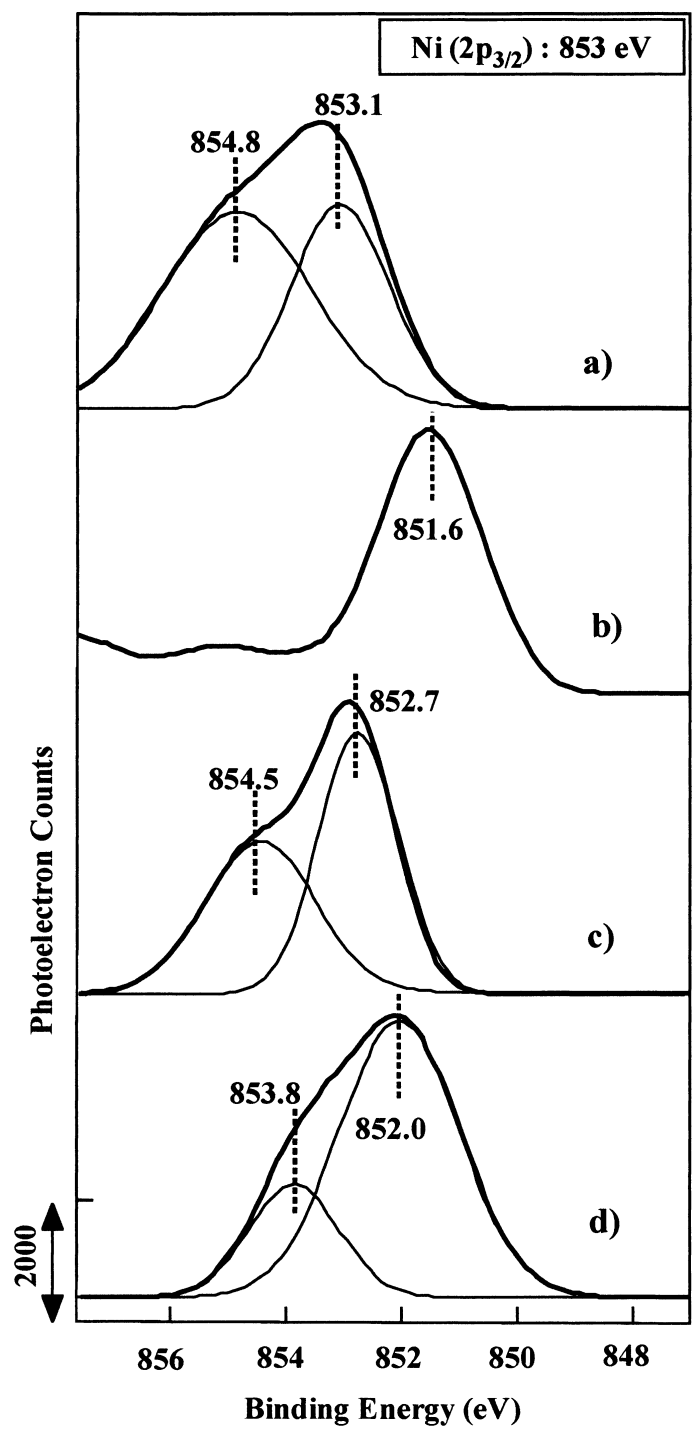

a) Fresh catalyst calcined in air at $723 \mathrm{~K}$ for $1 \mathrm{~h}$. b) Catalyst reduced with $\mathrm{H}_{2}$ at $873 \mathrm{~K}$ for $1 \mathrm{~h}$.

c) Catalyst (a) after the reaction with $\mathrm{CH}_{4} / \mathrm{O}_{2}$ at $973 \mathrm{~K}$ for $2 \mathrm{~h}$.

d) Catalyst (b) after the reaction with $\mathrm{CH}_{4} / \mathrm{O}_{2}$ at $973 \mathrm{~K}$ for $2 \mathrm{~h}$.

Fig. 1 X-Ray Photoelectron Spectra of Ni $2 \mathrm{p}_{3 / 2}$ on Nickel/Odia Catalyst

lysts were compared. Figure 1 shows the nickel species on O-dia in the fresh and reduced catalysts. Fresh calcined nickel/O-dia catalyst showed two peaks at 854.8 and $853.1 \mathrm{eV}$, which were ascribed to $\mathrm{Ni}_{2} \mathrm{O}_{3}$ and $\mathrm{NiO}$, respectively ${ }^{19)}$ (Fig. 1-a). The catalyst reduced with hydrogen at $873 \mathrm{~K}$ for $1 \mathrm{~h}$ (Fig. 1-b) had a strong peak at $851.6 \mathrm{eV}$, shifting from 854.8 and $853.1 \mathrm{eV}$, indicating that the nickel was reduced to metallic nickel. The binding energy of $\mathrm{NiO}$ is 854.0 $\mathrm{eV}$ for bulk $\mathrm{NiO}$, and $856.7 \mathrm{eV}$ for nickel oxide supported on alumina ${ }^{20)}$. Our finding is close to that for bulk NiO. The active form of supported nickel catalyst in partial oxidation is reported to be metallic nickel $^{21)}$.

XPS analysis of fresh nickel/O-dia catalyst used for the partial oxidation of methane found two nickel species, probably partially reduced oxides of $\mathrm{Ni}_{2} \mathrm{O}_{3-x}$ and $\mathrm{NiO}_{1-y}$ (Fig. 1-c). Peaks at 854.8 and $853.1 \mathrm{eV}$ of $\mathrm{Ni}(\mathrm{III})$ and $\mathrm{Ni}$ (II) (Fig. 1-a) shifted to slightly lower binding energy of 854.5 and $852.7 \mathrm{eV}$ (Fig. 1-c). XPS analysis of nickel/O-dia catalyst reduced under a hydrogen flow for $1 \mathrm{~h}$ at $873 \mathrm{~K}$, and used for the partial oxidation of methane at $973 \mathrm{~K}$ for $2 \mathrm{~h}$ showed the peaks at 854.8 and $853.1 \mathrm{eV}$ of $\mathrm{Ni}$ (III) and $\mathrm{Ni}$ (II) observed in Fig. 1-a had shifted to 853.8 and $852.0 \mathrm{eV}$ (Fig. 1-d). These peaks were ascribed to $\mathrm{Ni}_{2} \mathrm{O}_{3-x}$ and $\mathrm{NiO}_{1-y}$, which are slightly lower valence state oxides compared to those observed in Fig. 1-c. Therefore, partial oxidation of methane oxidized metallic nickel on the surface to nonstoichiometric nickel oxides, such as $\mathrm{Ni}_{2} \mathrm{O}_{3-x}$ and $\mathrm{NiO}_{1-y}$. Only a small portion of nickel oxide supported on magnesia was reduced to $\mathrm{Ni}(0)$. Similar findings were reported for nickel/alumina ${ }^{22}$. Such non-stoichiometric nickel oxide species seem to be the active forms of the nickel catalyst in partial oxidation. Except for the nickel/O-dia catalyst reduced with hydrogen, the half height width of the spectra varied, indicating that nickel oxides were present in different oxidation states. The reaction at $873 \mathrm{~K}$ resulted in considerable carbon formation, which prevented XPS measurement with a good signal to noise ratio.

XPS of the fresh and used nickel/silica catalysts are shown in Fig. 2. Fresh calcined nickel/silica catalyst showed two peaks at 855.0 and $853.2 \mathrm{eV}$, which were ascribed to $\mathrm{Ni}_{2} \mathrm{O}_{3}$ and $\mathrm{NiO}$, respectively, (Fig. 2-a), as in the case of Ni/O-dia catalyst. Catalyst reduced with hydrogen at $873 \mathrm{~K}$ for $1 \mathrm{~h}$ showed two peaks at 854.4 and $851.4 \mathrm{eV}$, ascribed to slightly reduced $\mathrm{Ni}_{2} \mathrm{O}_{3}$ and metallic nickel, respectively (Fig. 2-b). Compared with the spectrum shown in Fig. 1-b, a much larger peak was seen at $854.5 \mathrm{eV}$ in the nickel/silica catalyst, indicating that the stronger interaction between the nickel oxide and silica surface suppresses complete reduction of the oxide to metallic form. Such a difference in the reducibility of nickel oxide over different supports is also seen in nickel oxide on magnesia, calcium oxide, and cerium dioxide ${ }^{22)}$.

XPS analysis of fresh nickel/silica catalyst after partial oxidation of methane exhibited two peaks at 854.9 and $853.1 \mathrm{eV}$ (Fig. 2-c). The binding energies of the two peaks did not change after the reaction (compare Fig. 2-a and Fig. 2-c). In addition, partial oxidation of methane did not proceed at $973 \mathrm{~K}$ over nickel/silica catalyst without pretreatment with hydrogen. XPS analysis of nickel/silica catalysts reduced with hydrogen at $873 \mathrm{~K}$ for $1 \mathrm{~h}$, and after partial oxidation of methane at $973 \mathrm{~K}$ for $2 \mathrm{~h}$, found the peaks at 855.0 and $853.2 \mathrm{eV}$ (Fig. 2-a) shifted to slightly lower binding energy at 854.5 and $852.8 \mathrm{eV}$ (Fig. 2-d). These find- 


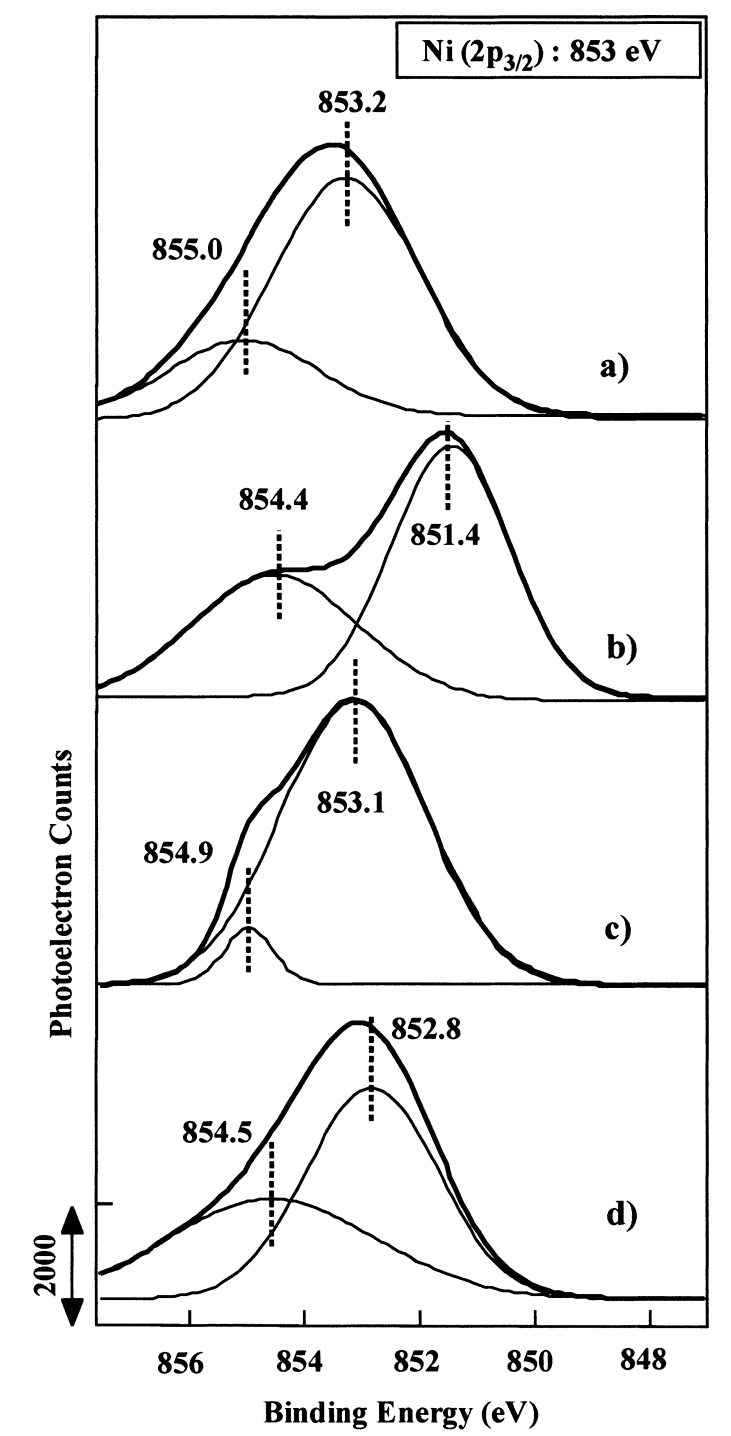

a) Fresh catalyst calcined in air at $723 \mathrm{~K}$ for $1 \mathrm{~h}$.

b) Catalyst reduced with $\mathrm{H}_{2}$ at $873 \mathrm{~K}$ for $1 \mathrm{~h}$.

c) Catalyst (a) after the reaction with $\mathrm{CH}_{4} / \mathrm{O}_{2}$ at $973 \mathrm{~K}$ for $2 \mathrm{~h}$.

d) Catalyst (b) after the reaction with $\mathrm{CH}_{4} / \mathrm{O}_{2}$ at $973 \mathrm{~K}$ for $2 \mathrm{~h}$.

Fig. 2 X-Ray Photoelectron Spectra of Ni $2 \mathrm{p}_{3 / 2}$ on $\mathrm{Nickel} / \mathrm{SiO}_{2}$ Catalyst

ings indicate that nickel oxide on silica could not be reduced to the metallic form or slightly reduced oxides in a flow of methane and oxygen. In addition, metallic nickel was oxidized during the reaction and appeared as higher binding energy oxide phases, compared to those observed in nickel species on O-dia. One possibility is that nickel oxide supported on O-dia is easily reduced to lower valence states as evidenced by the result in Fig. 1-b, due to weak interaction between the nickel oxide and O-dia surface.

\section{3. Active Species of Cobalt in the Cobalt/O-dia Catalyst}

Cobalt/O-dia catalyst exhibited high catalytic activity

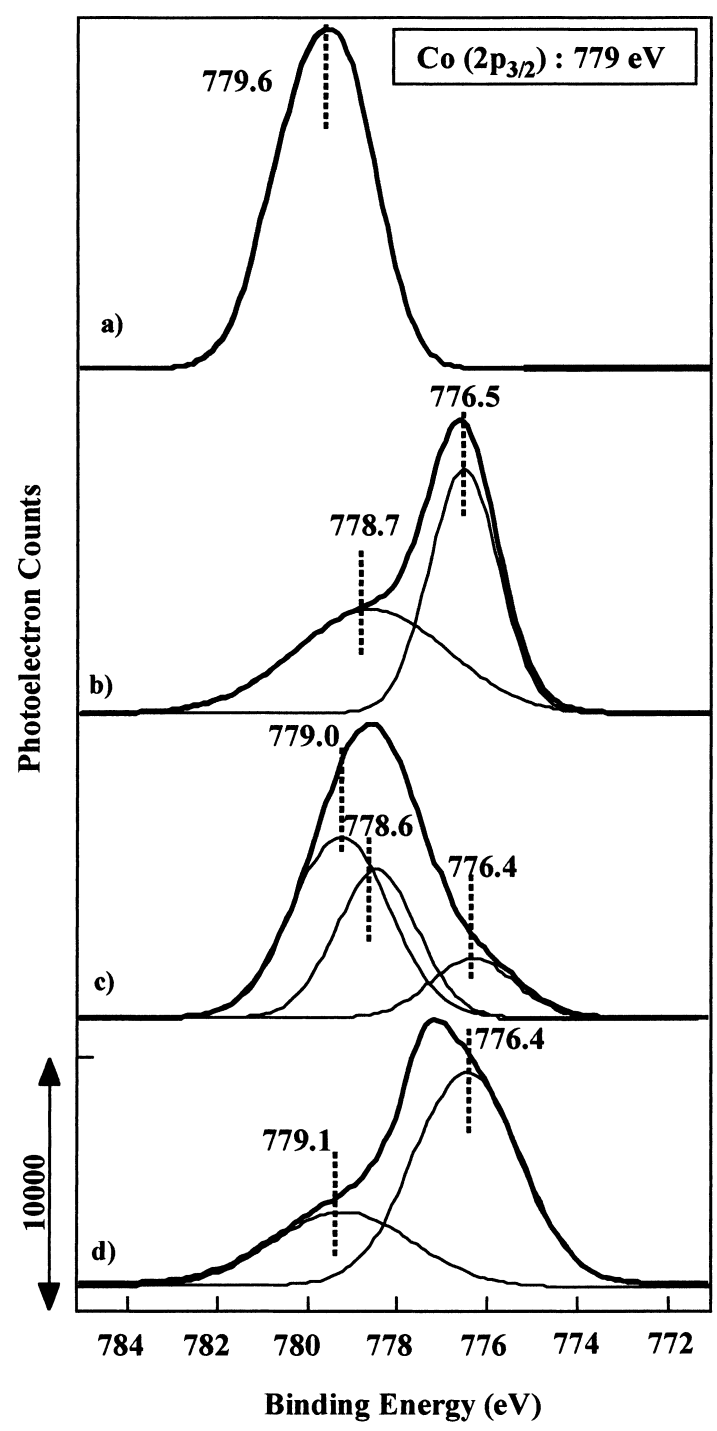

a) Fresh catalyst calcined in air at $723 \mathrm{~K}$ for $1 \mathrm{~h}$.

b) Catalyst reduced with $\mathrm{H}_{2}$ at $873 \mathrm{~K}$ for $1 \mathrm{~h}$.

c) Catalyst (a) after the reaction with $\mathrm{CH}_{4} / \mathrm{O}_{2}$ at $873 \mathrm{~K}$ for $2 \mathrm{~h}$.

d) Catalyst (b) after the reaction with $\mathrm{CH}_{4} / \mathrm{O}_{2}$ at $873 \mathrm{~K}$ for $2 \mathrm{~h}$.

Fig. 3 X-Ray Photoelectron Spectra of Co $2 \mathrm{p}_{3 / 2}$ on Cobalt/Odia Catalyst

for the partial oxidation of methane at $873 \mathrm{~K}$, but cobalt/silica and cobalt/alumina catalysts showed no activity at $873 \mathrm{~K}^{6}$. The cobalt species on both fresh and used catalysts were examined using XPS of cobalt/O-dia and cobalt/alumina catalyst and compared in Figs. 3 and 4. Cobalt/silica catalyst should be used for direct comparison, but cobalt/silica catalyst had no activity even after hydrogen reduction (Table 2). Fresh calcined cobalt/O-dia catalyst showed a peak at $779.6 \mathrm{eV}$, assignable to $\mathrm{Co}_{3} \mathrm{O}_{4}$ (Fig. 3-a), since the catalyst was prepared by calcination at $723 \mathrm{~K}$ under an air flow $^{23)}$. After reduction with hydrogen at $873 \mathrm{~K}$ for $1 \mathrm{~h}$ (Fig. 3-b), the peak appeared at $776.5 \mathrm{eV}$, a shift from 


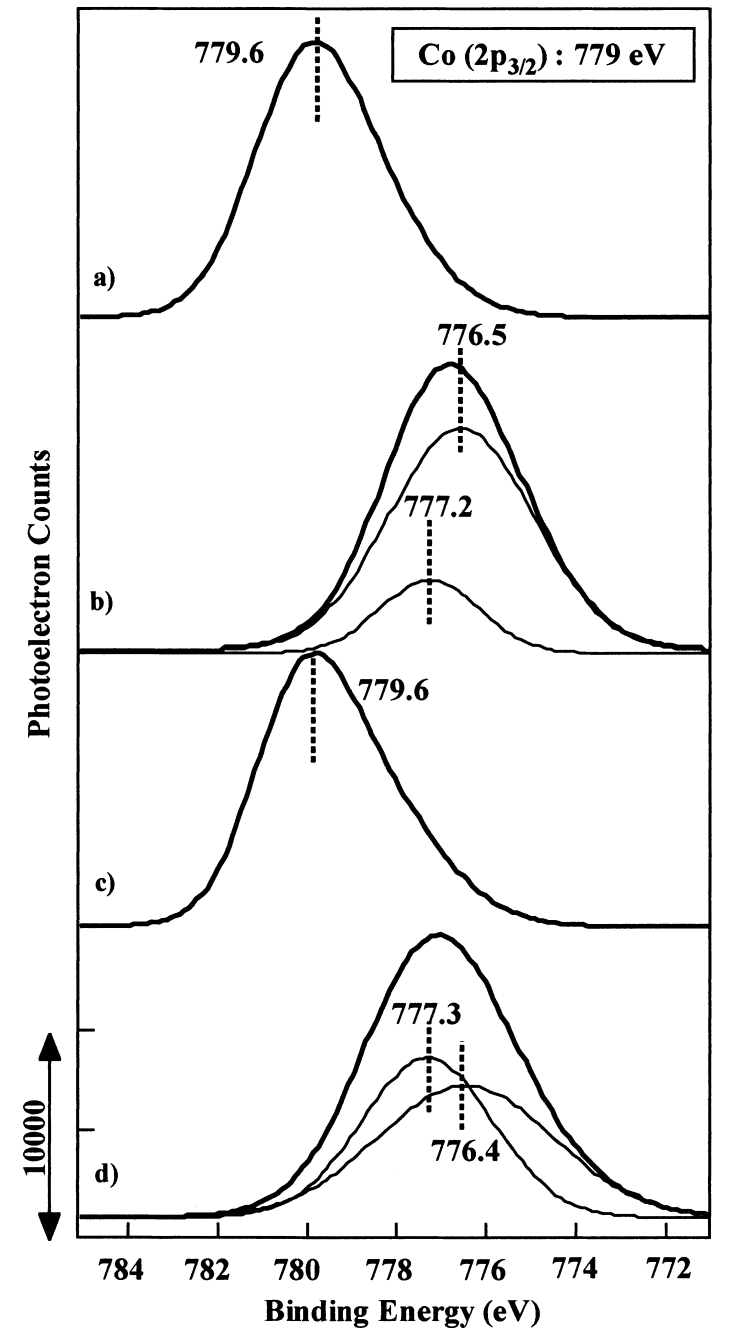

a) Fresh catalyst calcined in air at $723 \mathrm{~K}$ for $1 \mathrm{~h}$. b) Catalyst reduced with $\mathrm{H}_{2}$ at $873 \mathrm{~K}$ for $1 \mathrm{~h}$.

c) Catalyst (a) after the reaction with $\mathrm{CH}_{4} / \mathrm{O}_{2}$ at $873 \mathrm{~K}$ for $2 \mathrm{~h}$.

d) Catalyst (b) after the reaction with $\mathrm{CH}_{4} / \mathrm{O}_{2}$ at $873 \mathrm{~K}$ for $2 \mathrm{~h}$.

Fig. 4 X-Ray Photoelectron Spectra of Co $2 \mathrm{p}_{3 / 2}$ on Cobalt/ $/ \mathrm{Al}_{2} \mathrm{O}_{3}$ Catalyst

the higher binding energy of $779.6 \mathrm{eV}$, indicating that oxidic cobalt was reduced to metallic cobalt. This value is slightly lower compared to the reported values for metallic cobalt ${ }^{24), 25)}$. The weak broad peak at 778.7 $\mathrm{eV}$ could be ascribed to slightly reduced cobalt oxide $\left(\mathrm{CoO}_{1-x}\right)$. XPS analysis of the fresh cobalt/O-dia catalyst after partial oxidation of methane showed the skewed peak was deconvoluted into three cobalt species, $\mathrm{Co}_{3} \mathrm{O}_{4}(779.0 \mathrm{eV})$, slightly reduced $\mathrm{CoO}_{1-x}$ (778.6 eV), and metallic cobalt (776.4 eV) (Fig. 3-c). However, the intensity of the metallic cobalt species was weak. XPS analysis of the cobalt/O-dia catalyst reduced with hydrogen flow for $1 \mathrm{~h}$ at $873 \mathrm{~K}$, and after partial oxidation of methane at $873 \mathrm{~K}$ for $2 \mathrm{~h}$ detected two cobalt species $\mathrm{Co}_{3} \mathrm{O}_{4}(779.1 \mathrm{eV})$, and metallic cobalt (Fig. 3-d). When the reduced catalyst was used, metallic cobalt species remained during the reaction. However, conversion of methane with fresh and reduced catalyst was of the same order of magnitude (conversion, fresh catalyst: 22.9\%; hydrogen reduced catalyst: $21.2 \%$ ). Therefore, the XPS analyses suggest that the active species of cobalt/O-dia catalyst is both metallic cobalt and low valence state cobalt oxide (surface oxygen deficient species).

XPS analysis of fresh calcined cobalt/alumina catalyst showed a broader peak at $779.6 \mathrm{eV}$ ascribed to $\mathrm{Co}_{3} \mathrm{O}_{4}$ (Fig. 4-a), as for the cobalt/O-dia catalyst. After reduction of the catalyst with hydrogen at $873 \mathrm{~K}$ for $1 \mathrm{~h}$ (Fig. 4-b), a strong peak appeared at $776.5 \mathrm{eV}$, shifted from the higher binding energy of $779.6 \mathrm{eV}$ (Fig. 4-a), indicating that oxidic cobalt was reduced to metallic cobalt, and the peak at $777.2 \mathrm{eV}$ (Fig. 4-b) was ascribed to slightly reduced $\mathrm{CoO}_{1-x}$ oxide. Broader overlapping peaks indicated that reduction to metallic cobalt was not complete, compared to the cobalt/O-dia catalyst. The used cobalt/alumina catalyst showed almost the same spectrum as that of fresh catalyst, indicating that cobalt oxide was not reduced to low valence state cobalt oxides and metallic cobalt, in the course of the reaction with methane/oxygen mixture. Therefore, freshly prepared cobalt/alumina catalyst did not exhibit catalytic activity for the partial oxidation of methane at $873 \mathrm{~K}$ (Table 1). Such behavior is quite different from that of the cobalt/O-dia catalyst. XPS analysis of the cobalt/alumina catalyst reduced with hydrogen for $1 \mathrm{~h}$ at $873 \mathrm{~K}$, after partial methane oxidation at $873 \mathrm{~K}$ for $2 \mathrm{~h}$ exhibited two peaks at 777.3 and $776.4 \mathrm{eV}$, which were ascribed to oxygen deficient $\mathrm{CoO}_{1-x}$ and metallic cobalt (Fig. 4-d). Therefore, the reduced cobalt/alumina catalyst exhibited high catalytic activity for the partial oxidation of methane at $873 \mathrm{~K}$ (Table 2). Metallic or partially reduced $\mathrm{CoO}$ dispersed on rare earth oxide support is apparently the active site for the partial oxidation of methane ${ }^{27}$. These results suggest that cobalt/O-dia catalyst is reduced more easily than cobalt/alumina catalyst during the reaction with methane/oxygen.

The binding energy of metallic cobalt was lower than the reported value of $778.1 \mathrm{eV}$ in both catalysts ${ }^{16), 23) \sim 25)}$. As seen in Figs. 3 and 4, the binding energy of $\mathrm{Co}_{3} \mathrm{O}_{4}$ was the same value as reported. One possible explanation for our results is that a lower loading level of the cobalt was employed in our study $(5 \mathrm{wt} \%)$. The reduced catalysts did not show any XRD peaks of cobalt species, indicating that both the surface cobalt and the bulk cobalt species were fully reduced. In contrast, the fresh cobalt/O-dia catalyst showed diffraction peaks ascribed to $\mathrm{Co}_{3} \mathrm{O}_{4}$ species. No significant shake-up peak was observed in the XPS analyses, indicating that pure $\mathrm{Co}$ (II) species was not formed. 

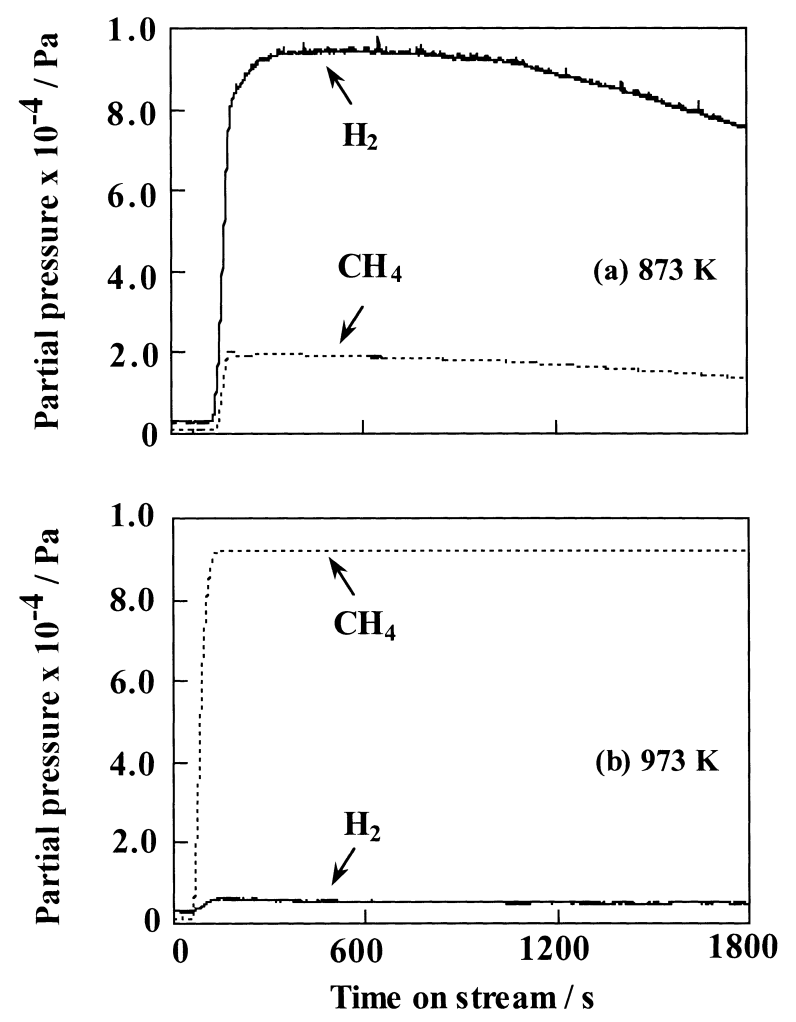

(a) Reaction at $873 \mathrm{~K}$, (b) reaction at $973 \mathrm{~K}$.

$\mathrm{CH}_{4}$ flow rate $=10 \mathrm{ml} / \mathrm{min}$, Catalyst: $100 \mathrm{mg}$.

Fig. 5 Transient Response Profile against Argon Flow to the Reaction of Methane over Nickel/O-dia Catalyst

\section{4. Transient Response Studies on Nickel/O-dia Catalyst}

The transient response reaction of methane was examined to obtain more information about the reaction pathway of synthesis gas production over nickel/O-dia catalyst. Before the reaction, the nickel/O-dia catalyst was reduced with hydrogen at $873 \mathrm{~K}$ for $1 \mathrm{~h}$, since nickel oxide on the catalyst surface could not be reduced with a pulse of methane/oxygen (2/1) mixed gas. Figure 5 shows hydrogen formation at 873 and $973 \mathrm{~K}$ when the flowing gas was switched from argon to pure methane (reaction 2). Hydrogen and unreacted methane were the only gaseous products observed. Rapid and continued production of hydrogen with a small response of methane was observed over nickel/Odia catalyst at $873 \mathrm{~K}$ (Fig. 5-a). On the other hand, only a very low concentration of hydrogen appeared instantaneously when methane was supplied to the nickel/O-dia catalyst at $973 \mathrm{~K}$ (Fig. 5-b). This is quite unusual for a chemical reaction to proceed less rapidly at a higher temperature. The reason seems to be different types of carbon formed on the nickel surface. The behavior shown in Fig. 5-b is quite similar to the result obtained for iridium/titania catalyst ${ }^{17}$.

Previously we demonstrated that reaction paths in
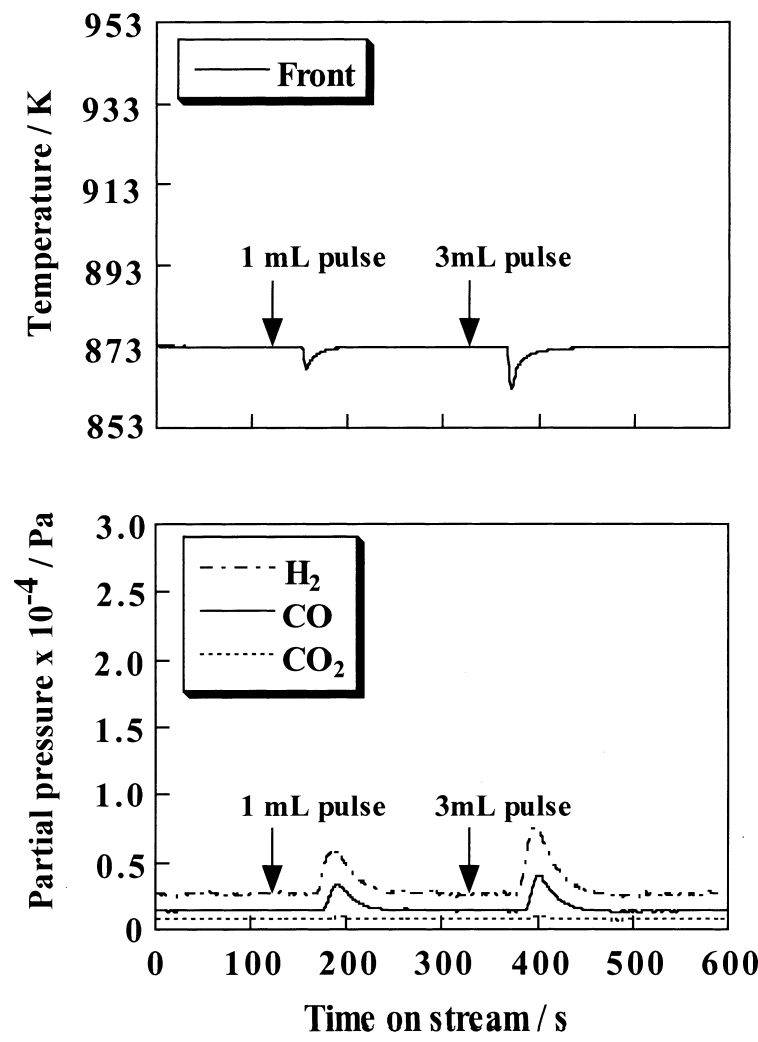

Reaction conditions: Ar carrier $=50 \mathrm{ml} / \mathrm{min}$, Mixed gas: $\mathrm{CH}_{4} / \mathrm{O}_{2}=$ $2(1 \mathrm{~m} l$ or $3 \mathrm{ml})$, Furnace temperature: $873 \mathrm{~K}$.

Fig. 6 Temperature Profiles at the Front Edge of the Catalyst Bed and Products after Pulsed Injection of $\mathrm{CH}_{4} / \mathrm{O}_{2}$ over Nickel (3 wt\%)/O-dia Catalyst at $873 \mathrm{~K}$

the partial oxidation of methane can be evaluated by the temperature changes at the catalyst bed during the methane/oxygen pulsed reaction ${ }^{17), 18)}$. A rapid temperature rise in the front edge of the iridium/titania catalyst bed was observed with the injection of a methane/oxygen $(2 / 1)$ pulse. On the other hand, a small but distinct temperature decrease was observed on the rhodium/titania catalyst bed at methane/oxygen pulse injection. These observations suggest that iridium/titania catalyzed, partial oxidation predominantly proceeds by sequential steps involving reactions (4), (5), and (6). In contrast, direct decomposition of methane occurs over rhodium/titania catalyst to hydrogen and carbon monoxide ${ }^{17), 18)}$.

The temperature at the front edge of the catalyst bed slightly decreased upon introduction of the methane/ oxygen pulse at $873 \mathrm{~K}$ as shown in Fig. 6. The synthesis gas production reactions (2), (5), and (6) are endothermic. Therefore, the above results (Figs. 5-a, and 6) suggest that hydrogen formation probably proceeded via methane decomposition (reaction 2), and then $\mathrm{CH}_{x}$ species generated on the nickel surface were oxidized to $\mathrm{CO}_{x}$ with either surface oxygen or vapor phase oxygen. The products were hydrogen and car- 

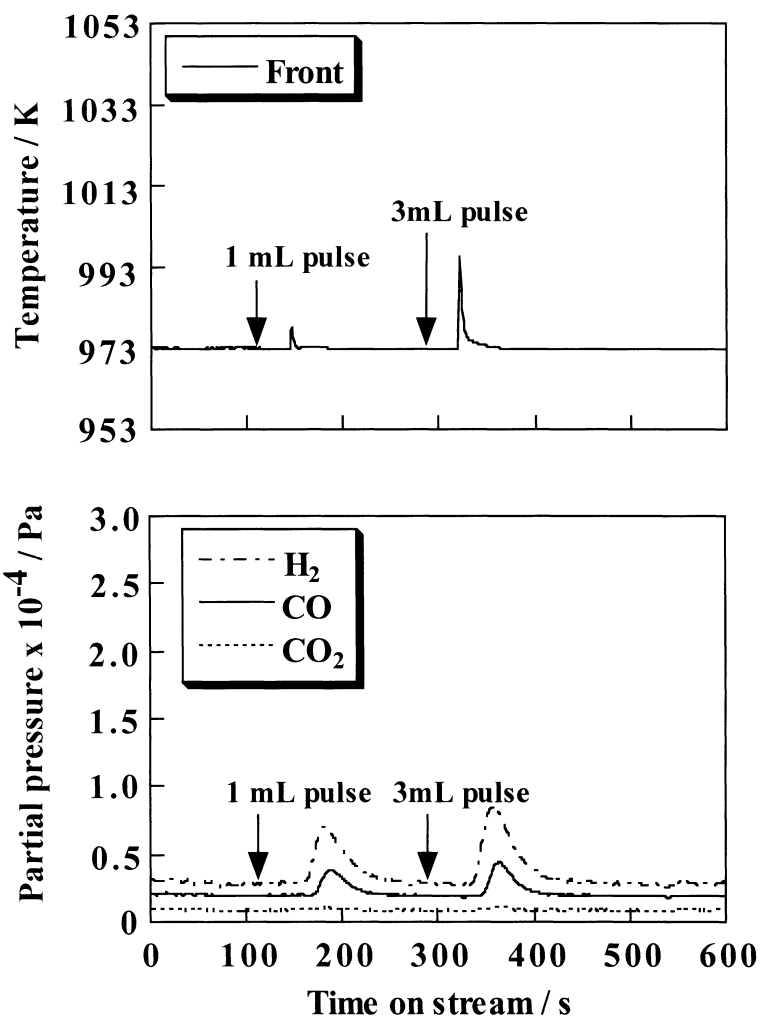

Reaction conditions: Ar carrier $=50 \mathrm{ml} / \mathrm{min}$, Mixed gas: $\mathrm{CH}_{4} / \mathrm{O}_{2}=$ $2(1 \mathrm{~m} l$ or $3 \mathrm{~m} l)$, Furnace temperature: $973 \mathrm{~K}$.

Fig. 7 Temperature Profiles at the Front Edge of the Catalyst Bed and Products after Pulsed Injection of $\mathrm{CH}_{4} / \mathrm{O}_{2}$ over Nickel (3 wt\%)/O-dia Catalyst at $973 \mathrm{~K}$

bon monoxide as seen in Fig. 6-b. These results are consistent with the findings of continuous flow partial oxidation of methane with oxygen, in which considerable amount of carbon formation was observed during reaction at $873 \mathrm{~K}^{6}$.

Methane decomposition on the nickel surface is the most important key reaction in the direct oxidation of methane to form synthesis gas. Nickel catalysts are very active for methane decomposition ${ }^{27)}$ 29). Moreover, direct formation of carbon monoxide and hydrogen formation from methane without intermediate total oxidation using nickel-containing catalysts is possible ${ }^{30)}$. Therefore, partial oxidation of methane via the direct path is not peculiar to the nickel/O-dia catalyst.

Figure 7 shows the transient temperature responses of the nickel/O-dia catalyst during pulsed injection of methane/oxygen (2/1) at $973 \mathrm{~K}$. A small sudden rise in temperature at the front edge of the catalyst bed was observed at the methane/oxygen (2/1) pulse. This temperature increase can be ascribed to the exothermic complete oxidation reaction (4). Carbon monoxide and hydrogen were obtained together with a small amount of carbon dioxide (pulse size $3 \mathrm{ml}$ ). These results strongly suggest that synthesis gas formation over nickel/

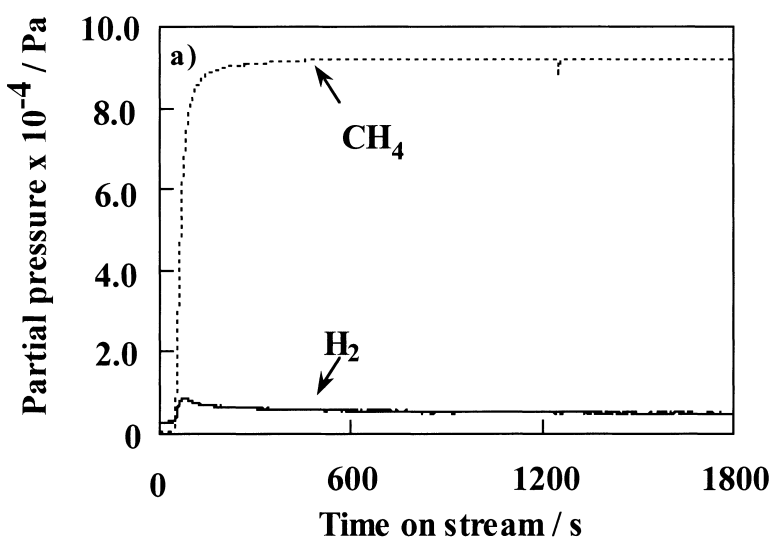

$\mathrm{H}_{2}$ reduction: $\mathrm{H}_{2}=10 \mathrm{~m} / / \mathrm{min}, 873 \mathrm{~K}, 1 \mathrm{~h}$, Temperature: $873 \mathrm{~K}$, Catalyst: $100 \mathrm{mg}, \mathrm{CH}_{4}$ flow rate $=10 \mathrm{ml} / \mathrm{min}$.

Fig. 8 Transient Response against Reaction of Methane over Cobalt/O-dia Catalyst

O-dia catalyst at $973 \mathrm{~K}$ may proceed via a two-step pathway: total oxidation of methane to carbon dioxide and water (reaction 4), followed by reforming to synthesis gas (reactions 5 and 6), as indicated previously for the iridium/titania catalyst ${ }^{17), 18}$. Carbon dioxide is produced by complete oxidation of methane, whereas the slower carbon dioxide reforming reaction of methane forms unreacted carbon dioxide. Our results showed that higher carbon dioxide selectivity was obtained at $973 \mathrm{~K}$, although the equilibrium is less favorable for carbon dioxide (Table $\mathbf{1}$ ).

\section{5. Transient Response Studies on Cobalt/O-dia Catalyst}

Cobalt/O-dia catalyst shows slightly different behavior compared to nickel/O-dia catalyst ${ }^{6}$. Methane conversion was higher at lower temperature and no carbon deposition was seen after the reaction at any temperature. The transient pulse method was used to investigate the differences in the nickel/O-dia catalyst and cobalt/O-dia catalyst.

Figure 8 shows hydrogen formation over the cobalt/O-dia catalyst when the flowing gas was switched from argon to methane at $873 \mathrm{~K}$ (reaction 2). Before the reaction, the cobalt/O-dia catalyst was reduced with hydrogen at $873 \mathrm{~K}$ for $1 \mathrm{~h}$. When methane was supplied to the cobalt/O-dia catalyst, only a small hydrogen response appeared and then decreased to a low concentration. This behavior is quite different from that observed for the nickel/O-dia catalyst at $873 \mathrm{~K}$, indicating that only slight methane decomposition occurred. This behavior was the same as that observed in the reaction with nickel/O-dia at $973 \mathrm{~K}$.

A sudden rise in temperature at the front edge of the cobalt/O-dia catalyst bed was observed at methane/oxygen pulses (Fig. 9). The temperature rise increased with larger pulse size from 1.0 to $3.0 \mathrm{ml}$. The temper- 

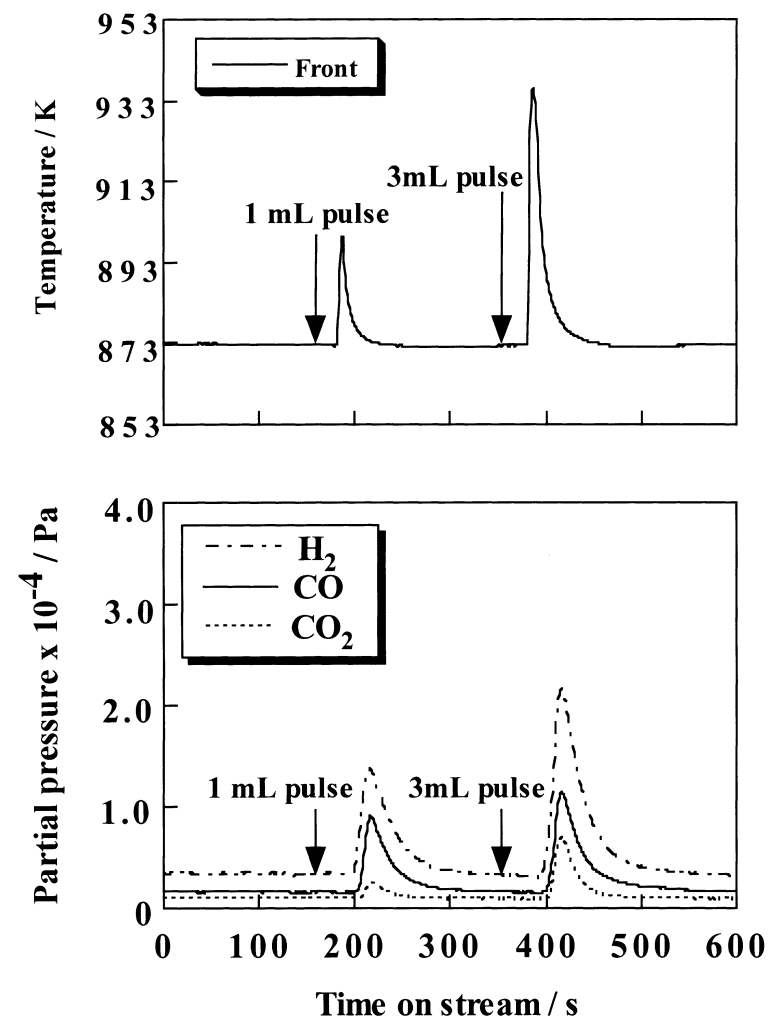

Reaction conditions: Ar carrier $=10 \mathrm{ml} / \mathrm{min}$, Mixed gas: $\mathrm{CH}_{4} / \mathrm{O}_{2}=$ $2(1 \mathrm{~m} l$ or $3 \mathrm{ml})$, Furnace temperature: $873 \mathrm{~K}$.

Fig. 9 Temperature Profiles at the Front Edge of the Catalyst Bed and Products after Pulsed Injection of $\mathrm{CH}_{4} / \mathrm{O}_{2}$ over Cobalt (3 wt\%)/O-dia Catalyst at $873 \mathrm{~K}$

ature increase in the front edge of the catalyst bed can be ascribed to the exothermic complete oxidation reaction. As in the case of the nickel/O-dia catalyst at 973 $\mathrm{K}$, carbon monoxide and hydrogen together with a considerable amount of carbon dioxide were obtained from the methane/oxygen pulse. These results strongly suggest that synthesis gas formation over cobalt/O-dia catalyst may proceed via two-step pathways, as for the iridium/titania catalyst ${ }^{17}$. Carbon dioxide and water were produced by the complete oxidation reaction in the front edge of the catalyst bed. Slower carbon dioxide and steam reforming reactions followed to form hydrogen and carbon monoxide. The reaction of carbon dioxide with methane over nickel and cobalt/Odia catalysts was discussed previously ${ }^{11}$. A large amount of unreacted carbon dioxide was observed, whereas almost no carbon dioxide was detected from the nickel/O-dia catalyst in the pulsed reaction at $873 \mathrm{~K}$ (Fig. 6). All these results suggest that different reaction pathways occur over the nickel/O-dia catalyst at $873 \mathrm{~K}$ and the nickel/O-dia catalyst at $973 \mathrm{~K}$ and cobalt/O-dia catalyst at any temperature.

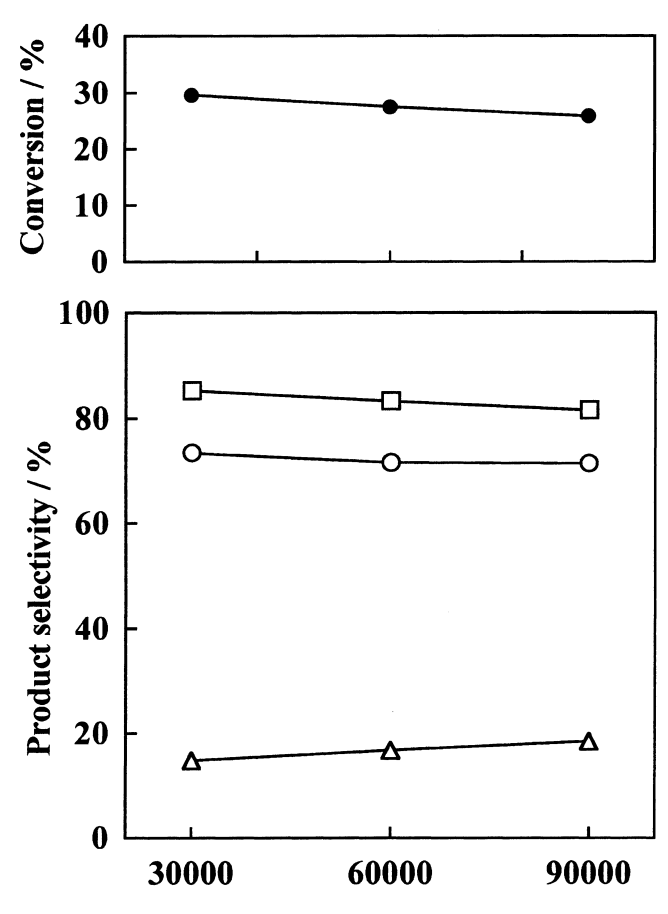

Space velocity / $\mathbf{r}^{1} \mathbf{~ m L} / g$ cat

Catalyst: 50-150 mg, Reaction temperature: $973 \mathrm{~K}$.

$\mathrm{O}: \mathrm{H}_{2}, \square: \mathrm{CO}, \triangle: \mathrm{CO}_{2}$.

Fig. 10 Effect of Space Velocity on $\mathrm{CH}_{4}$ Conversion and Product Selectivities over Nickel (3 wt\%)/O-dia Catalyst

\section{6. Effect of Space Velocity in the Partial} Oxidation of Methane on the Product Distribution over Ni and Co/O-dia Catalysts

Among the reactions involved in the partial oxidation of methane, complete oxidation is the fastest, and carbon dioxide reforming is the slowest. The effect of the space velocity on the product distribution gives information about the reaction course. Figure 10 shows the conversion of methane and selectivities for carbon monoxide, hydrogen and carbon dioxide as a function of the space velocity over nickel/O-dia catalyst at $973 \mathrm{~K}$. The methane conversion and the carbon monoxide and hydrogen selectivities decreased with increasing space velocity. On the other hand, the carbon dioxide selectivity increased. These results suggest that two-step reaction pathways are important in synthesis gas formation. If the partial oxidation proceeds via the one-step process (reaction 1), an increase in the space velocity would decrease the conversion of methane without changing the hydrogen and carbon monoxide selectivities.

Similarly with cobalt/O-dia catalyst, the space velocity was varied by increasing the feed rate at $873 \mathrm{~K}$. Figure 11 shows the methane conversion and selectiv- 

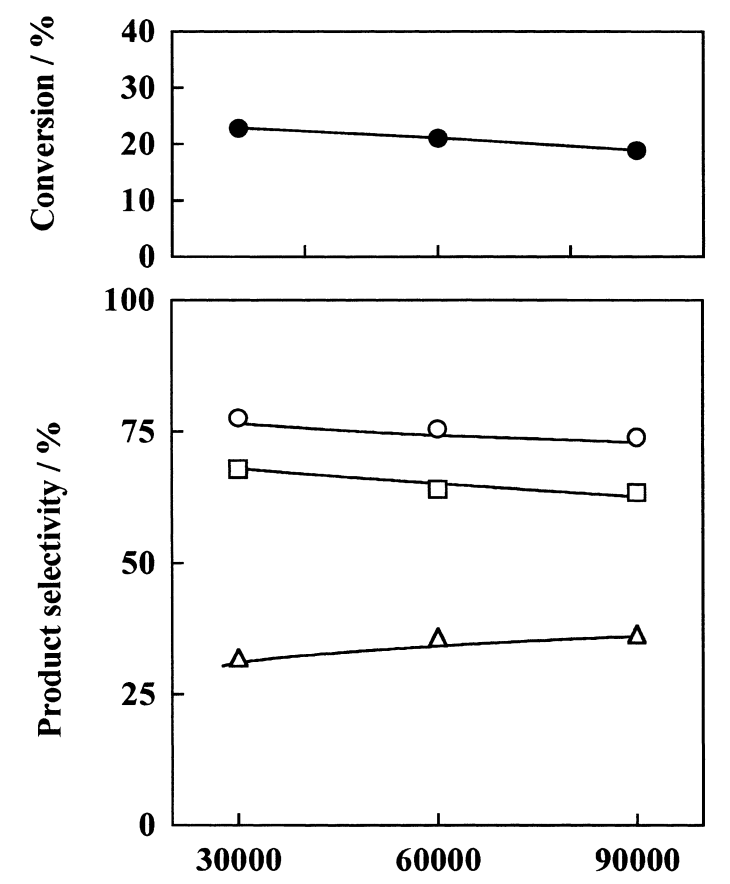

\section{Space velocity $/ \mathrm{h}^{-1} \mathrm{~mL} / \mathrm{g}$-cat}

Catalyst: 50-150 mg, Reaction temperature: $873 \mathrm{~K}, \mathrm{CH}_{4} / \mathrm{O}_{2}=5$, Flow rate: $30 \mathrm{ml} / \mathrm{min} . \quad \bigcirc: \mathrm{H}_{2}, \square: \mathrm{CO}, \triangle: \mathrm{CO}_{2}$.

Fig. 11 Effect of Space Velocity on $\mathrm{CH}_{4}$ Conversion and Product Selectivities over Cobalt $(3 \mathrm{wt} \%) / \mathrm{O}-\mathrm{dia}$ Catalyst

ities for carbon monoxide, hydrogen and carbon dioxide as a function of the space velocity. Exactly the same behavior was observed, indicating that the twostep pathway occurs in partial oxidation over cobalt/Odia catalyst.

These results show that carbon deposition behavior during partial oxidation of methane at $873 \mathrm{~K}$ over nickel/ $\mathrm{O}$-dia is due to the decomposition of methane to carbon and hydrogen (reaction 2). The reason why no carbon deposition was observed on the same catalyst at $973 \mathrm{~K}$ is the change in the reaction mechanism from methane decomposition to complete oxidation (reaction 4). The reason for such a change in mechanism could not be interpreted in this study. Thermodynamic calculation shows that $\Delta G$ for reaction (2) is negative at $873 \mathrm{~K}$ and becomes more negative with higher reaction temperature. Higher activation energy of complete oxidation may be one of the reasons for the change in reaction mechanism. The weak capability for the decomposition of methane (reaction 2) and higher oxidation ability of cobalt/O-dia catalyst resulted in the two-step reaction pathway, irrespective of the reaction temperature.

\section{Conclusion}

The active forms of nickel and cobalt species on $\mathrm{O}$ dia catalyst in the partial oxidation of methane were examined by XPS and compared to inactive catalysts. Reduced forms of both nickel oxide and cobalt oxide phases were found to be the active phases. The presence of the metallic form is not essential to the catalytic activity. Reduction of oxides did not proceed in methane and oxygen flows over nickel/silica and cobalt/alumina catalysts.

Reaction mechanisms of the partial oxidation of methane with nickel/O-dia catalyst and cobalt/O-dia catalyst to give synthesis gas differ at $873 \mathrm{~K}$, as the reaction proceeded through the direct path to give hydrogen and carbon on the nickel/O-dia catalyst surface, whereas two-step complete oxidation followed by reforming occurred over cobalt/O-dia catalyst, irrespective of the temperature.

\section{Acknowledgment}

This work was financially supported by a Grant-inAid for Scientific Research (10555283 and 14350429). We thank Professor S. Nishiyama of Kobe University for his interpretation of X-ray photoelectron spectra.

\section{References}

1) Aschcroft, A. T., Cheetham, A. K., Food, J. S., Green, M. L. H., Grey, C. P., Murrel, A. J., Vernon, P. D., Nature, 344, 319 (1990).

2) Tsang, S. C., Claridge, J. B., Green, M. L. H., Catal. Today, 23, 3 (1995).

3) York, A. P. E., Xiao, T. C., Green, M. L. H., Topics in Catal., 22, 345 (2003).

4) Bharadwaj, S. S., Schmidt, L. D., Fuel Process. Technol., 42, 109 (1995).

5) Hickman, D. A., Schmidt, L. D., Science, 259, 343 (1993).

6) Nishimoto, H., Nakagawa, K., Ikenaga, N., Gamo, M. N., Ando, T., Suzuki, T., Appl. Catal. A: General, 264, 65 (2004).

7) Nakagawa, K., Nishimoto, H., Enoki, Y., Egashira, S., Ikenaga, N., Kobayashi, T., Gamo, M. N., Ando, T., Suzuki, T., Chem. Lett., 30, 460 (2001).

8) Nakagawa, K., Hashida, T., Kajita, C., Ikenaga, N., Kobayashi, T., Gamo, M. N., Suzuki, T., Ando, T., Catal. Lett., 80, 161 (2002).

9) Nakagawa, K., Kajita, C., Ikenaga, N., Suzuki, T., Kobayashi, T., Gamo, M. N., Ando, T., J. Phys. Chem. B, 107, 4048 (2003).

10) Okumura, K., Nakagawa, K., Shimamura, T., Ikenaga, N., Gamo, M. N., Ando, T., Kobayashi, T., Suzuki, T., J. Phys. Chem. B, 107, 13419 (2003).

11) Nakagawa, K., Nishimoto, H., Kikuchi, M., Egashira, S., Enoki, Y., Ikenaga, N., Gamo, M. N., Ando, T., Suzuki, T., Energy \& Fuels, 17, 971 (2003).

12) Ando, T., Yamamoto, K., Ishii, M., Kamo, M., Sato, Y., J. Chem. Soc., Faraday Trans., 89, 3635 (1993).

13) Wang, S. B., Lu, G. Q., Appl. Catal. A: General, 169, 271 (1998).

14) Burattin, P., Che, M., Louis, C., J. Phys. Chem. B, 104, 10482 (2000).

15) Wang, W. J., Chen, Y. W., Appl. Catal. A: General, 72, 223 
(1991).

16) Ji, L., Lin, J., Zeng, H. C., J. Phys. Chem. B, 104, 1783 (2000)

17) Nakagawa, K., Ikenaga, N., Teng, Y., Kobayashi, T., Suzuki, T., J. Catal., 186, 405 (1999).

18) Nakagawa, K., Ikenaga, N., Kobayashi, T., Suzuki, T., Catal. Today, 64, 31 (2001).

19) Zhu, T., Stephanopoulos, M. F., Appl. Catal. A: General, 208, 403 (2001).

20) Hou, Z., Yokota, O., Tanaka, T., Yashima, T., Appl. Catal. A: General, 253, 381 (2003).

21) Dissanayake, D., Rosyneck, M. P., Kharas, K. C. C., Lunsford, J., J. Catal., 132, 117 (1992).

22) Tang, C. S., Lin, J., Tan, K. L., Catal. Lett., 51, 169 (1998).

23) Bianchi, C. L., Catal. Lett., 76, 155 (2001).
24) Tang, S., Lin, J. L., Tan, K. L., Catal. Lett., 59, 129 (1999).

25) Backman, L. B., Rautiainen, A., Lindblad, M., Jylha, O., Krause, A. O. I., Appl. Catal. A: General, 208, 223 (2001).

26) Choudhary, V. R., Rajput, A. M., Rane, V. H., Catal. Lett., 16, 269 (1992)

27) Ermakova, M. A., Ermakov, D. Yu., Kuvshinov, G. G., Plyasova, L. M., J. Catal., 187, 77 (1999).

28) Ermakova, M. A., Ermakov, D. Yu., Kuvshinov, G. G., Appl. Catal. A: General, 201, 61 (2000).

29) Villacampa, J. I., Royo, C., Romeo, E., Montoya, J. A., Del Angel, P., Monzon, A., Appl. Catal. A: General, 252, 363 (2003).

30) Tulenin, Y. P., Sinev, M. Y., Savkin, V. V., Korchak, V. N., Catal. Today, 91, 155 (2004).

\section{要旨}

\section{酸化ダイヤモンド担持触媒を用いたメタンの部分酸化反応による合成ガス生成}

\section{一ニッケルおよびコバルトの触媒挙動一}

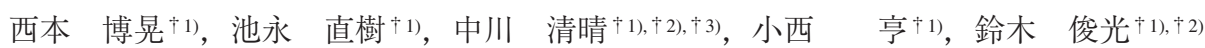

†1) 関西大学工学部化学工学科, 564-8680 大阪府吹田市山手町 3-3-35

†2) 関西大学ハイテクリサーチセンター，564-8680 大阪府吹田市山手町3-3-35

†3) 科学技術振興機構および物質・材料研究機構，305-0044 茨城県つくば市並木 1-1

メタンの部分酸化反応における酸化ダイヤモンド担持ニッケ ルおよびコバルト触媒（Ni/O-dia触媒抒よびCo/O-dia触媒）の キャラクタリゼーションをXPS (X-ray photoelectron spectroscopy) および transient response 法を用いて行った。

$873 \mathrm{~K}$ でのメタンの部分酸化反応において，Co/O-dia触媒を 用いたときには触媒表面上への炭素析出は見られなかったが， Ni/O-dia触媒を用いたときには炭素が析出した。各反応後の触 媒をXPS で分析すると，Ni/O-dia触媒では部分的に還元された 酸化ニッケル種が認められ，Co/O-dia触媒では 0 価のコバルト， 部分的に還元された酸化コバルト種および酸化コバルト (III) の存在が確認された。一方， $873 \mathrm{~K} に$ 保持した触媒にメタンの
みを供給したところ，Ni/O-dia触媒ではメタン供給と同時に多 量の水素が生成したが，Co/O-dia触媒ではわずかな量の水素し か生成しなかった。さらに, メタン／酸素混合ガス (2:1) を パルスで供給したところ，Ni/O-dia触媒では吸熱が起こり， Co/O-dia触媒では発熱が起こった。以上のことを考え合わせる と, Ni/O-dia触媒ではまずメ夕ンの分解によって水素が生成し, 残った炭素種が酸素と反応し一酸化炭素が生成するものと考え られる。Co/O-dia触媒ではメタンの完全酸化が起こり，生成し た水打よび二酸化炭素によるメタンの改質反応によって合成ガ スが生成するものと考えられる。 